This observation has not been previously reported, and as yet there is no satisfactory explanation for it.

During the harmattan season evaporative water loss is increased because of the low relative humidity. The latent heat lost from the body causes a feeling of cold, and shivering may occur. Cold can cause a reflex retraction of the testis, as seen in patients whose testes retract when an examiner's hands are cold. Anatomical variations such as the bell clapper anomaly, a long mesorchium, and a separated epididymis have been described in patients undergoing surgery for testicular torsion. In such patients reflex contraction of the testicular capsule, dartos, or cremasteric muscle has been postulated to be the mechanism initiating torsion. ${ }^{1}$

In both winter and harmattan people wear more clothes to keep warm. Might the amount of clothing worn be related to the torque that causes the retracting testis to undergo torsion? Toddlers and infants in this rural community traditionally do not wear nappies, which might perhaps account for the paucity of young children in this series.
Whatever the cause of testicular torsion, the condition accounts for $11 \%$ of all orchidectomies in Zaria and is, therefore, an important contributor to male infertility.

I thank the director, Institute of Agricultural Research, Ahmadu Bello University, Zaria, for the meteorological data and Dr P Singha for performing the statistical analyses.

\section{References}

1 Shukla RB, Kelly DG, Daly L, Guiney EJ. Association of cold weather with testicular torsion. $\mathrm{Br}$ Med f 1982;285:1459-60.

Williamson R. Cold weather and testicular torsion. Br Med f 1983;286:1436.

2 Williamson R. Cold weather and testicular torsion. Br Med J 1983;286:1436.

3 Preshaw RM. Seasonal frequency of testicular torsion. Can J Surg 1984;27:404-5.

4 Edwards JH. The recognition and estimation of cyclic trends. Ann Hum Genet 1961;25:83-7.
5 Mabogunje OA, Grundy DJ, Lawrie JH. Orchidectomy in a rural African population. Trans $R$ So Mabogunje OA, Grundy DJ, Law
Trop Med Hyg 1980;74:749-51.

(Accepted 30 August 1985)

\title{
Vagal slowing of the heart during haemorrhage: observations from 20 consecutive hypotensive patients
}

\author{
K SANDER-JENSEN， $\mathrm{N}$ H SECHER， P BIE， J WARBERG， T W SCHWARTZ
}

\begin{abstract}
Heart rate and arterial blood pressure were monitored in 20 consecutive patients during resuscitation from haemorrhagic shock. The mean blood loss $(2 \cdot 3$ (SEM 0.3) 1) corresponded to $36(4) \%$ of their estimated mean blood volume. During shock the mean blood pressure was $81 / 55(3 / 2) \mathrm{mm} \mathrm{Hg}$ and heart rate 73 (3) beats/min. Administration of blood and crystalloids resulted in immediate increases to $111 / 72(2 / 2) \mathrm{mm} \mathrm{Hg}$ and $102(3)$ beats $/ \mathrm{min}$ followed by steady state values of $131 / 79$ (6/3) $\mathrm{mm} \mathrm{Hg}$ and 82 (2) beats/min. In three otherwise healthy patients plasma concentrations of the vagally regulated hormone pancreatic polypeptide rose from resting values of $64-77 \mathrm{pmol} / 1(272-327 \mathrm{pg} / \mathrm{ml})$ to $198-280 \mathrm{pmol} / \mathrm{l}(842-1190 \mathrm{pg} / \mathrm{ml})$.
\end{abstract}

These findings suggest that reversible hypotensive hypovolaemic shock is characterised by a decrease in heart rate conceivably reflecting an increase in vagal tone.

\footnotetext{
Departments of Surgery A and Anaesthesia, Glostrup Hospital, DK-2600 Glostrup, Denmark

K SANDER-JENSEN, MD, research fellow

N H SECHER, MD, PHD, senior registrar in anaesthesia

Department of Medical Physiology C, Panum Institute, DK-2200 Copenhagen $\mathbf{N}$, Denmark

P BIE, MD, PHD, associate professor

J WARBERG, MD, PHD, associate professor

Department of Clinical Chemistry, Rigshospitalet, DK-2100 Copenhagen $\emptyset$, Denmark

T W SCHWARTZ, MD, PHD, MRC professor

Correspondence to: Dr Kåre Sander-Jensen, Department of Medical Physiology C, Panum Institute, DK-2200 Copenhagen N, Denmark.
}

\section{Introduction}

Circulatory homoeostasis is dependent on the intravascular volume and its distribution. Redistribution of the blood volume induced by head up tilt (reverse Trendelenburg's position), lower body negative pressure, and venous congestion of the legs during constriction by pneumatic cuffs is associated with tachycardia and vasoconstriction provided that blood pressure is maintained. A moderate increase in heart rate to $80-90$ beats/min (certainly below 130 beats $/ \mathrm{min}$ ) is typical. ${ }^{1}$ During progressive central hypovolaemia circulatory control is suddenly changed. Blood pressure and heart rate decrease concomitantly with a decrease in total peripheral resistance, and syncope and nausea may occur. These manifestations of severe central hypovolaemia also occur during induced haemorrhage. ${ }^{23}$ Yet in current textbooks the "vasovagal" reaction to bleeding has largely been ignored. ${ }^{4}$ One reason may be that bradycardia during hypotensive haemorrhagic shock is documented only as casuistic reports ${ }^{5-8}$ where relative bradycardia has led to diagnostic difficulty.

Intensive care medicine provides the opportunity for systematic observations of heart rate during hypotension due to haemorrhage. We have analysed the recordings of heart rate and blood pressure of 20 consecutive patients who presented in haemorrhagic shock. To evaluate the effects of oxygen tension on heart rate during shock arterial blood samples were obtained in five patients. Pancreatic polypeptide, a hormone under vagal control, '9 was also measured in five patients. In these patients also arginine vasopressin concentrations in plasma were measured in order to evaluate the relevance of increased concentrations to the decrease in heart rate ${ }^{10}$ and pallor of patients in shock. ${ }^{11}$

\section{Patients and methods}

We collected data on consecutive patients who presented with symptoms of shock, including hypotension due to haemorrhage. During the study period 12 men and eight women (one of whom died) came to our attention. The mean (SEM) loss of blood was $2 \cdot 3(0.3) 1$, corresponding to $36(4) \%$ of their estimated total mean blood volume (see table). Haemorrhage occurred from internal as well as external lesions. The patients were initially treated 
with $2 \cdot 0(0 \cdot 3) 1$ blood and $20 \%$ albumin solution and $3.3(0.4) 1$ crystalloids intravenously. Because of the urgent need for volume replacement blood samples during shock were obtained from only eight patients. Five patients had by chance been fasting for at least eight hours, and in these cases plasma pancreatic polypeptide and arginine vasopressin concentrations were measured. Venous blood samples were collected into chilled tubes, centrifuged at $4^{\circ} \mathrm{C}$, and kept at $-20^{\circ} \mathrm{C}$ and arginine vasopressin and pancreatic polypeptide values analysed by radioimmunoassays..$^{12}$ Oxygen tension was measured in arterial blood samples using an ABL-2 (R) analyser (Radiometer, Copenhagen). Heart rate and blood pressure were measured by electrocardiography and auscultation, respectively.

Values are expressed as means (SEM) and were compared using Student's $t$ test for paired observations.

\section{Results}

During shock the mean systolic and diastolic blood pressure was $81 / 55$ (3/2) $\mathrm{mm} \mathrm{Hg}$ and mean heart rate 73 (3) beats/min (table, figure). With the administration of blood, albumin, and crystalloids blood pressure increased to $111 / 72(2 / 2) \mathrm{mm} \mathrm{Hg}$ and heart rate to $102(3)$ beats/min in the immediate recovery period, then stabilised at $131 / 79(6 / 3) \mathrm{mm} \mathrm{Hg}$ and $82(2)$ beats $/ \mathrm{min}$,

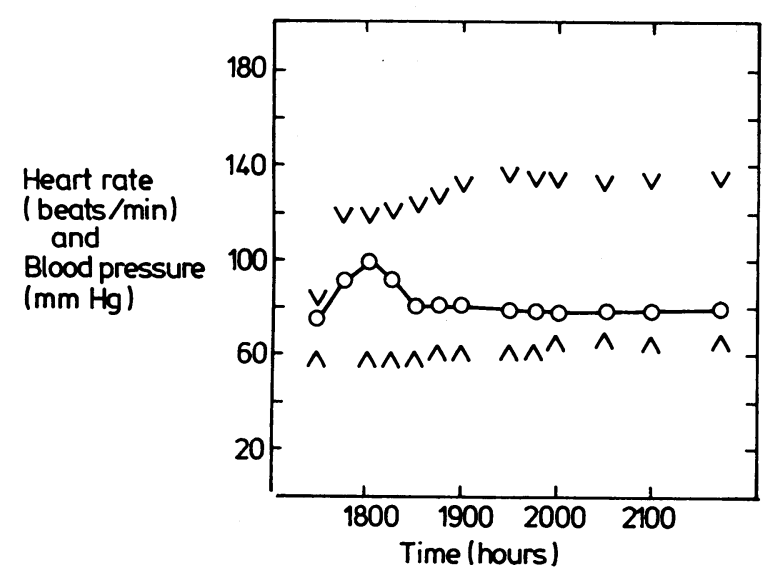

Case 2. Heart rate $\left(\mathrm{O}_{-} \mathrm{O}\right)$ and systolic $(\mathrm{V})$ and diastolic $(\Lambda)$ arterial blood pressure during intravenous administration of blood, albumin, and saline. respectively. Heart rate during shock was 9 (3) beats/min lower $(p<0.01)$, and during recovery 20 (2) beats/min higher, than the steady state value $(p<0.001)$. The figure shows a typical example of the time course of the changes in heart rate and blood pressure during treatment; heart rate increased to a maximum within 30 minutes, and steady state values were achieved after one hour of replacement therapy.

During the hypotensive bradycardiac episode pancreatic polypeptide concentrations in plasma ranged from 198 to $280 \mathrm{pmol} / \mathrm{l}(842-1190 \mathrm{pg} / \mathrm{ml})$ in three patients (table). In two patients with autonomic neuropathy pancreatic polypeptide did not increase during the hypotensive bradycardiac episode, remaining at 20 and $53 \mathrm{pmol} / \mathrm{l}(85$ and $225 \mathrm{pg} / \mathrm{ml}$ ) respectively. Control fasting pancreatic polypeptide values ranged from 32 to $77 \mathrm{pmol} / 1$ (136 to 327 $\mathrm{pg} / \mathrm{ml}$ ). Arginine vasopressin concentrations in plasma ranged from 3 to 64 $\mathrm{pmol} / \mathrm{l}(3-69 \mathrm{pg} / \mathrm{ml}$ ) (table); control values were below $1.5 \mathrm{pmol} / 1(1.6 \mathrm{pg} / \mathrm{ml})$. The mean arterial oxygen tension was $13 \cdot 1(1 \cdot 7) \mathrm{kPa}(98 \cdot 5(12 \cdot 8) \mathrm{mm} \mathrm{Hg})$ (table). In shock all patients were cold and pale.

\section{Discussion}

These patients had lost roughly a third of their total blood volume from various lesions. In the cases of external haemorrhage measurements of heart rate were of little relevance for the diagnosis of bleeding and determining blood and fluid requirements. When haemorrhage was not evident-for example, in patients with gastritis or lesions in the mesocolon-the relatively low heart rate misled the clinician; digitalis intoxication was suspected in case 5 (table) and gastric bleeding diagnosed only after the development of aspiration pneumonia. In case 7 an emotionally induced "vasovagal" reaction was suspected. This is understandable in view of the emphasis on tachycardia in haemorrhagic shock in current textbooks, where bradycardia is interpreted as a sign of irreversible shock. ${ }^{4}$

The gastric stimulus exerted by the proteinaceous blood in bleeding gastritis may have explained the high pancreatic polypeptide value in case 11 but not in the two other patients (cases 1 and 8), who bled from a radial artery and lesions in the mesentery and spleen, respectively. Two patients (cases 18 and 19) suffered from overt autonomic neuropathy; pancreatic polypeptide cannot increase in this condition ${ }^{13}$ and indeed did not do so in either of these cases. The release of pancreatic polypeptide concomitant with the decrease in heart rate in these otherwise healthy bleeding patients as well as in fasting normal subjects with hypotension induced by head up tilt ${ }^{14}$

Clinical and laboratory details of 20 patients with bleeding

\begin{tabular}{|c|c|c|c|c|c|c|c|c|c|c|c|c|c|}
\hline \multirow[b]{2}{*}{$\begin{array}{l}\text { Case } \\
\text { No }\end{array}$} & \multirow[b]{2}{*}{ Sex } & \multirow[b]{2}{*}{$\begin{array}{c}\text { Age } \\
\text { (years) }\end{array}$} & \multirow[b]{2}{*}{$\begin{array}{l}\text { Weight } \\
(\mathrm{kg})\end{array}$} & \multirow[b]{2}{*}{$\begin{array}{l}\text { Blood } \\
\text { loss } \\
(1)\end{array}$} & \multicolumn{2}{|c|}{$\begin{array}{l}\text { Intravenous } \\
\text { treatment }\end{array}$} & \multicolumn{2}{|c|}{$\begin{array}{l}\text { Findings during } \\
\text { shock phase }\end{array}$} & \multicolumn{2}{|c|}{$\begin{array}{l}\text { Findings during } \\
\text { recovery phase }\end{array}$} & \multicolumn{2}{|c|}{$\begin{array}{l}\text { Steady state } \\
\text { findings }\end{array}$} & \multirow[b]{2}{*}{$\begin{array}{c}\text { Cause of bleeding and } \mathrm{PP}(\mathrm{pmol} / \mathrm{l}), \\
\mathrm{AVP}(\mathrm{pmol} / \mathrm{l}) \text {, and } \mathrm{Po}_{2}(\mathrm{kPa}) \text { values during } \\
\text { shock phase }\end{array}$} \\
\hline & & & & & $\underset{(1)}{\text { Saline }}$ & $\begin{array}{l}\text { Blood } \\
\text { and } \\
\text { albumin } \\
\text { (I) }\end{array}$ & $\begin{array}{l}\text { Blood } \\
\text { pressure } \\
(\mathrm{mm} \mathrm{Hg})\end{array}$ & $\begin{array}{c}\text { Heart } \\
\text { rate } \\
\text { (beats/ } \\
\text { min) }\end{array}$ & $\begin{array}{c}\text { Blood } \\
\text { pressure } \\
(\mathrm{mm} \mathrm{Hg})\end{array}$ & $\begin{array}{l}\text { Heart } \\
\text { rate } \\
\text { (beats/ } \\
\text { min) }\end{array}$ & $\begin{array}{c}\text { Blood } \\
\text { pressure } \\
(\mathrm{mm} \mathrm{Hg})\end{array}$ & $\begin{array}{c}\text { Heart } \\
\text { rate } \\
\text { (beats/ } \\
\text { min) }\end{array}$ & \\
\hline 1 & $\mathbf{F}$ & 65 & 50 & $1 \cdot 8$ & $4 \cdot 0$ & $1 \cdot 4$ & $60 /-$ & 60 & $100 / 70$ & 120 & $130 / 80$ & 80 & $\begin{array}{l}\text { Left radial artery lesion; } \\
\text { PP 198; AVP 64, } \mathrm{PO}_{2} 18.9\end{array}$ \\
\hline 2 & $\mathbf{F}$ & 74 & 41 & $2 \cdot 1$ & 3.0 & $2 \cdot 2$ & $80 / 60$ & 75 & $115 / 60$ & 100 & $135 / 70$ & 80 & Gastric ulcer \\
\hline 3 & $\mathbf{F}$ & 30 & 57 & $3 \cdot 0$ & $4 \cdot 0$ & 1.8 & $70 / 40$ & 70 & $110 / 70$ & 112 & $110 / 70$ & 90 & Extrauterine pregnancy \\
\hline 4 & $\mathbf{M}$ & 51 & 83 & $2 \cdot 0$ & $3 \cdot 0$ & $1 \cdot 4$ & $100 / 65$ & 60 & $120 / 75$ & 110 & $115 / 60$ & 80 & Oesophageal varices \\
\hline 5 & $\mathbf{F}$ & 53 & - & - & $2 \cdot 0$ & $1 \cdot 0$ & $85 / 55$ & 80 & $100 / 60$ & 100 & $110 / 65$ & 80 & Gastritis \\
\hline 6 & $M$ & 19 & - & $5 \cdot 0$ & $4 \cdot 0$ & 3.7 & $65 /-$ & 82 & $100 / 60$ & 120 & $120 / 80$ & 100 & Right atrial lesion; $\mathrm{PO}_{2} 9 \cdot 1$ \\
\hline 7 & $\mathbf{M}$ & 52 & 100 & 1.5 & $5 \cdot 3$ & 1.5 & $75 /-$ & 78 & $110 / 70$ & 100 & $180 / 105$ & 80 & Lesion in mesocolon \\
\hline 8 & M & 46 & 70 & $2 \cdot 0$ & $5 \cdot 0$ & 3.9 & $80 /-$ & 80 & $110 / 80$ & 100 & $160 / 75$ & 96 & Mesentery and spleen lesions; PP 280, AVP 44 \\
\hline 9 & $\mathbf{F}$ & 44 & - & 6.0 & 6.0 & $4 \cdot 2$ & $80 /-$ & 80 & - & - & - & - & $\begin{array}{l}\text { Multiple trauma; died } \\
\text {. }\end{array}$ \\
\hline 10 & $\mathbf{F}$ & 47 & 53 & - & $3 \cdot 0$ & 0.6 & $90 / 60$ & 75 & $130 / 90$ & 100 & $105 / 70$ & 75 & Haemorrhoids \\
\hline 11 & $M$ & 39 & 76 & $2 \cdot 0$ & 1.5 & 0.6 & $90 / 50$ & 76 & $110 / 60$ & 128 & $120 / 85$ & 84 & Gastritis; PP 215, AVP 3 \\
\hline 12 & $\mathbf{M}$ & 84 & - & $2 \cdot 0$ & $2 \cdot 0$ & 1.8 & $90 /-$ & 46 & $120 / 80$ & 110 & $160 / 105$ & 80 & Aortic aneurysm \\
\hline 13 & $\mathbf{F}$ & 24 & 60 & $1 \cdot 0$ & $4 \cdot 6$ & $3 \cdot 1$ & $75 / 60$ & 70 & $110 / 80$ & 70 & $130 / 80$ & 64 & Right carotic artery and jugular vein lesions \\
\hline 14 & $\mathbf{M}$ & 62 & - & $3 \cdot 0$ & $2 \cdot 7$ & 3.5 & $100 / 60$ & 60 & $120 / 80$ & 115 & $190 / 110$ & 92 & Ruptured spleen; $\mathrm{Po}_{2} 11 \cdot 4$ \\
\hline 15 & $\mathbf{M}$ & 26 & - & $2 \cdot 3$ & $3 \cdot 5$ & $1 \cdot 0$ & $80 / 60$ & 80 & $100 / 70$ & 100 & $120 / 85$ & 80 & Right facial artery lesion \\
\hline 16 & $\mathbf{M}$ & 25 & 70 & 0.8 & $4 \cdot 0$ & $3 \cdot 3$ & $100 / 60$ & 80 & $110 / 70$ & 100 & $120 / 70$ & 78 & Meckel's diverticulum \\
\hline 17 & $\mathbf{M}$ & 63 & 70 & $2 \cdot 0$ & 4.8 & $2 \cdot 8$ & $65 /-$ & 78 & $110 / 80$ & 98 & $140 / 70$ & 78 & Right iliac aneurysm; $\mathbf{P o}_{2} 11 \cdot 1$ \\
\hline 18 & $\mathbf{M}$ & 46 & 60 & $2 \cdot 0$ & 1.0 & 1.0 & $80 / 60$ & 60 & $110 / 70$ & 78 & $130 / 75$ & 70 & Left radial artery lesion; PP 20, AVP $3 ; P_{2} 15 \cdot 1$ \\
\hline 19 & $\mathbf{M}$ & 41 & 72 & $2 \cdot 0$ & 1.5 & 0.7 & $70 / 40$ & 98 & $100 / 70$ & 100 & $110 / 70$ & 88 & Oesophageal varices; PP 53, AVP 41 \\
\hline 20 & $\mathbf{F}$ & 91 & 60 & $1 \cdot 0$ & 0.5 & $1 \cdot 0$ & $80 / 50$ & 72 & $120 / 65$ & 84 & $120 / 70$ & 74 & Right femoral artery lesion \\
\hline $\begin{array}{l}\text { Mean } \\
\text { SEM }\end{array}$ & & $\begin{array}{r}49 \\
4\end{array}$ & $\begin{array}{r}65 \\
5\end{array}$ & $\begin{array}{l}2 \cdot 3 \\
0 \cdot 3\end{array}$ & $\begin{array}{l}3 \cdot 3 \\
0 \cdot 4\end{array}$ & $\begin{array}{l}2 \cdot 0 \\
0 \cdot 3\end{array}$ & $\begin{array}{c}81 / 55 \\
3 / 2\end{array}$ & $\begin{array}{r}73 \\
3\end{array}$ & $111 / 72$ & $\begin{array}{r}102 \\
3\end{array}$ & $\begin{array}{c}131 / 79 \\
6 / 3\end{array}$ & $\begin{array}{r}82 \\
2\end{array}$ & \\
\hline
\end{tabular}


suggests a widespread increase in vagal tone. Atropine abolishes the bradycardia of hypovolaemia induced hypotension'; this finding supports the possibility that an increase in vagal cholinergic tone is responsible for the bradycardia during haemorrhage.

The comparatively low heart rate during hypotension was not due to a low arterial oxygen tension. It has been suggested that bradycardia during haemorrhagic shock might be caused by the release of arginine vasopressin..$^{10} \mathrm{~A}$ low heart rate, however, was seen even in the two patients with an arginine vasopressin concentration of only $3 \mathrm{pmol} / \mathrm{l}(3 \mathrm{pg} / \mathrm{ml})$, and in a separate series the heart rate was unchanged in subjects given an infusion of arginine vasopressin resulting in a mean concentration of $42 \mathrm{pmol} / 1$ $(46 \mathrm{pg} / \mathrm{ml})$. This value is similar to the highest concentrations measured during shock in the present study. At the same time, infusion of arginine vasopressin results in severe pallor and a sharp decrease in subcutaneous blood flow as measured by xenon-133 washout. "In two of the present patients pallor occurred despite an arginine vasopressin concentration of only $3 \mathrm{pmol} / 1$. Thus mechanisms other than an increase in arginine vasopressin concentration must contribute to the pallor of patients in shock.

A pronounced increase in heart rate undoubtedly may occur concomitant with hypovolaemic hypotension ${ }^{15}$; this, however, may be due to causes other than haemorrhage. Plainly anxiety, pain, and medication may increase the heart rate. Possibly a haemorrhage induced decrease in blood pressure to values below those recorded in our patients may elicit a forceful stimulation of the sympathetic system resulting in an increase in heart rate. Hoffman described a bleeding patient whose hypotension $(96 / 56 \mathrm{~mm} \mathrm{Hg})$ and bradycardia ( 68 beats/min) were followed by a further decrease in blood pressure $(36 / 0 \mathrm{~mm} \mathrm{Hg})$ concomitant with an increase in heart rate $(120$ beats/min) and whose state of shock was still reversible. ${ }^{8}$ Thus relative bradycardia during haemorrhage may be time limited, as occurs in rats. ${ }^{16}$

In animals hypotensive haemorrhage elicits a reflex bradycardia through vagal afferent $C$ fibres from the left ventricle of the heart, ${ }^{3}{ }^{17}$ the bradycardia being abolished by atropine or cutting the vagus. ${ }^{3}$ The mechanism of activation of the ventricular receptors is probably a combined effect of an increased sympathetic outflow and a lowered ventricular filling. These two stimuli together induce a powerful contraction around an almost empty chamber, giving rise to deformation and squeezing of the myocardium, which activates the receptors. ${ }^{3}$ This reflex mechanism, of which the efferent part seems similar to so called vasovagal syncope, may serve as a protective mechanism allowing for improved diastolic filling when venous return is critically reduced. ${ }^{3}$

We conclude that a vagally mediated decrease in heart rate is a regular finding during hypotensive, severe haemorrhage. The observed bradycardia in man may be evoked by activation of cardiac depressor reflexes and may thus represent a clinical equivalent to the findings in animals.

This study was supported by the Danish Space Board.

\section{References}

1 Blomquist CG, Stone HL. Cardiovascular adjustments to gravitational stress. In: Handbook of physiology. Washington, DC: American Physiological Society, 1984:968-1025.

2 Barcroft H, Edholm OG, McMichael J, Sharpey-Schafer EP. Posthaemorrhagic fainting, study by cardiac output and forearm flow. Lancet 1944;i:489-91.

3 Öberg B, White S. The role of vagal cardiac nerves and arterial baroreceptors in the circulatory adjustments to hemorrhage in the cat. Acta Physiol Scand 1970;80:395-403. Clin Physiol 1985;5:315-23.

5 Hyun BH, Varga CF, Rubin RJ, Plainfield NJ. Spontaneous and pathologic rupture of the spleen.

6 Jansen RPS. Relative bradycardia: a sign of acute intraperitoneal bleeding. Aust NZ 7 Obstet Gynaecol 1978;18:206-8.

7 Secher NH, Sander-Jensen K, Werner C, Warberg J, Bie P. Bradycardia during severe but reversible hypovolemic shock in man. Circ Shock 1984;14:267-74.

8 Hoffman RL. Rupture of the spleen. A review and report of a case following abdominal hysterectomy. Am 7 Obstet Gymecol 1972;133:524-8.

9 Schwartz TW. Pancreatic polypeptide: a hormone under vagal control. Gastroenterology 1983;85:1411-25.

10 Bennett T, Gardiner SM. Involvement of vasopressin in cardiovascular regulation. Cardiovasc Res 1985;19:57-68.

11 Bie P, Astrup A, Secher NH, Sander-Jensen K, Warberg J. Hemodynamic effects of synthetic

12 Bie $P$, Warberg J. Effects on intravascular pressures of vasopressin and angiotensin II in dogs. Am I Physiol 1983;245:R906-14.

13 Krarup T, Schwartz TW, Hilsted J, Madsbad S, Verlaege O, Sestoft L. Impaired response of pancreatic polypeptide to hypoglycaemia: an early sign of autonomic neuropathy in diabetics. BrMed I 1979;ii:1544-6.

14 Sander-Jensen K, Secher NH, Astrup A, et al. Hypotension induced by passive head-up tilt: endocrine and circulatory mechanisms. Submitted for publication.

15 Grant RT, Reeve EB. Clinical observations on air-raid casualties. BrMed f 1941;ii:293-7, 329-32.

16 Häggendal $\mathrm{J}$. About the sympathetic activity in rats during hemorrhage indicated by heart rate and blood levels of catecholamines [A bstract]. Acta Physiol Scand 1985;123:31a.

17 Thorén P. Role of cardiac vagal C-fibers in cardiovascular control. Rev Physiol Biochem Pharmacol 1979;86:1-94.

(Accepted 31 October 1985)
4 Secher NH, Bie P. Bradycardia during reversible haemorrhagic shock, a forgotten observation? Arch Surg 1972;104:652-7. arginine vasopressin in man [Abstract]. Acta Physiol Scand 1984;121:10a.

\section{YEARS AGO}

The reluctance with which coroners accede to the demand for post mortem examinations is well known, and has been the subject of a good deal of criticism. Even in cases where the cause of death is shrouded in the greatest obscurity, they do not hesitate, unless circumstances point plainly to poisoning, or to some form of violent death, to content themselves with a vaguely worded verdict, which, to all intents and purposes, might as well have been left unsaid. The assumption would seem to exist that a person found dead died a natural death, in the absence of outward and visible signs to the contrary. It may, however, be argued with a great show of reason that exactly the opposite rule ought to hold; that any death, not duly certified by a qualified person, should be held as the result of other than natural causes until the contrary was proved by scientific witnesses to be the case. Were this the golden rule, the slipshod and desultory opinion of a friend, or, it may even be, of a medical man who has casually examined the body, as to the cause of death being "probably" heart-disease or apoplexy, would no longer be accepted, and one more loophole of escape would be closed to possible malpractices. The non-medical coroners are, as a rule, far more answerable for this state of things than the jury, who, inexperienced and ignorant of their rights and privileges, are unable to do more than protest against the peremptory and dictatorial tone of the crown-officer. The attitude of coroners in the matter is possibly not unconnected with their pecuniary dependence on local authorities, who are not, as a rule, remarkable for their perspicacity in matters scientific. The constantly recurring and undignified struggles between the late Dr. Edwin Lankester and the Middlesex magistrates showed what was likely to befal a man who really carried out his mission in an exhaustive manner.

An excellent precedent was created this week at an inquest, of which we give a full notice, held before Mr. William Carter, Coroner for East Surrey. The body of a newly born male child had been found under a railway arch by some children, and was at once taken to a neighbouring medical man for examination, and he pronounced death to have taken place quite recently. The coroner, however, did not think proper to summon this gentleman to give evidence, "as there was no legal proof of the child having had a separate existence from its mother." A juror very pertinently asked where the coroner expected to get such evidence in the absence of a medical man; but he was promptly told to sit down and be silent, under penalty of being sent to prison for contempt of court. This extraordinary threat only called forth expression of unanimous dissatisfaction from the jury, who, through their foreman, declined to conduct themselves as "dummies," and insisted on the post mortem examination being made. The coroner, of course, had no option but to order this to be done, and the inquiry was adjourned for the purpose, and to allow the attendance of $\mathrm{Mr}$. Farr, the medical man who saw the body in the first instance.

We must congratulate the jury on its courage and pertinacity; and we trust that examples will not be wanting, to show that the citizens who are called upon to act in this responsible and thankless capacity are awakening to a sense of their duties to the public, in a matter of such import as the determining the exact cause of death. It should be remembered that the slightest omission or neglect of, it may be, an apparently insignificant detail of evidence, may be the cause of a murder remaining undetected.

(British Medical Fournal 1886;i:355.) 